\title{
Sposób żywienia nastoletnich pacjentów chorych na wrzodziejące zapalenie jelita grubego, chorobę Leśniowskiego-Crohna i celiakię a morfologia krwi
}

\author{
Diet of teenagers with ulcerative colitis, Crohn's disease and coeliac disease versus \\ their blood morphology
}

\author{
Małgorzata Szczuko ${ }^{\bowtie}$, Nina Konecka, Justyna Kikut, Weronika Klimczyk \\ Pomorski Uniwersytet Medyczny w Szczecinie, Zakład Biochemii i Żywienia Człowieka, ul. Broniewskiego 24, 71-460 Szczecin \\ $\triangle$ malgorzata.szczuko@pum.edu.pl
}

\begin{abstract}
Introduction: Patients with chronic intestinal diseases suffer from nutrient deficiency.

The aim of the study was to show the differences in the diet and nutrient supply, as well as to demonstrate the need for supplementation in the group of adolescents.

Materials and methods: The study group comprised 26 people. Subgroups formed by subjects suffering from ulcerative colitis (UC), Crohn's disease (CD) and coeliac disease comprised 8, 8 and 10 people, respectively. Both sexes were equally represented in groups. The age of patients was $15.57 \pm 2.50,15.75 \pm 1.75,14.8 \pm 1.99$ years, respectively.

Dietary intake was assessed on the basis of a 24-hour dietary recall entered in the dietary software Dieta $5 \mathrm{~d}$ recommended by National Food and Nutrition Institute. Obtained results were compared to current nutritional standards. The measurements of body mass, height and blood morphology were used to assess the differences in nutritional status. The data were subjected to statistical analysis with Statistica 12 using T-test for the samples independent from the groups.

Results: Energy intake in all analysed groups was insufficient. The group of patients suffering from coeliac disease consumed the fewest calories. The largest statistically significant differences were shown between coeliac disease and UC. They related to the lower total intake of protein and all amino acids except lysine. In the same group we determined a significantly lower consumption of vitamins E, C, pyridoxine, thiamine and folic acid as well as almost all mineral compounds. Additionally, a lower
\end{abstract}

intake of essential fatty acids, starch and dietary fibre was noted in patients with coeliac disease, as compared to CD and UC. The fewest statistically significant differences were shown among the patients suffering from CD and UC. The consumption of calcium in all analysed groups was insufficient to cover daily demand. Statistical analysis of blood morphology results revealed significant differences in the number of monocytes in patients with CD and UC. Among those suffering from CD and coeliac disease the statistically significant difference referred to RDW-CV, whereas among the patients with UC and coeliac disease the difference related to erythrocytes, haematocrit and MCV.

Conclusions: The assessment of the diet and blood morphology revealed that all tested groups are prone to malnutrition. The caloric load of the diet of people suffering from coeliac disease can be increased through the addition of starch from gluten-free sources. Supplementation with calcium and vitamin D should be introduced in all groups at the same level. Additionally, due to insufficient supply with the diet, the supplementation of potassium, magnesium and folacin should be considered, especially in coeliac disease and CD groups. In the case of coeliac disease, the supplementation should also include vitamin E, zinc, iron and iodine. The intake of dietary fibre in coeliac disease may be insufficient. The reduction in the number of erythrocytes and haematocrit can suggest the occurrence of UC. Lower values for platelets, especially RDW-CV (\%), can increase the risk of coeliac disease. The increase in monocytes may be characteristic for CD. Keywords: ulcerative colitis; Crohn's disease; celiac disease; nutritional status; diet; teenagers.

\begin{abstract}
ABSTRAKT
Wstęp: Pacjenci z przewlekłymi chorobami jelit często cierpią na niedobory składników pokarmowych.

Celem pracy było wskazanie różnic w sposobie żywienia, podaży składników odżywczych i pokarmowych oraz wykazanie konieczności suplementacji w grupie nastolatków.

Materiały i metody: Grupę badaną stanowiło 26 osób: 8 z wrzodziejącym zapaleniem jelita grubego (WZJG), $8 \mathrm{z}$ chorobą Leśniowskiego-Crohna (CD) oraz $10 \mathrm{z}$ celiakią. Były to grupy o równym udziale obu płci. Wiek pacjentów wynosił odpowiednio $15,57 \pm 2,50,15,75 \pm 1,75$ oraz $14,8 \pm 1,99$ lat.

Sposób żywienia oceniono na podstawie wywiadu o spożyciu z ostatnich 24 godz., wprowadzonego do programu dietetycznego Dieta 5d rekomendowanego przez Instytut Żywności i Żywienia.
\end{abstract}

Uzyskane wyniki porównano z aktualnymi normami żywienia. W ocenie różnic stanu odżywienia wykorzystano pomiar masy ciała i wzrostu oraz morfologię krwi. Dane poddano analizie statystycznej przy użyciu programu Statistica 12, wykorzystując test T dla prób niezależnych względem grup.

Wyniki: Spożycie energii we wszystkich analizowanych grupach jest niewystarczające. Grupa pacjentów chorujących na celiakię spożywała najmniej kalorii. Najwięcej różnic statystycznie istotnych wykazano pomiędzy celiakią a WZJG. Odnosiły się one do niższego spożycia białka ogółem oraz wszystkich aminokwasów z wyjątkiem lizyny. W tej samej grupie wykazano istotnie niższe spożycie witamin E, C, pirydoksyny, tiaminy i kwasu foliowego, a także prawie wszystkich składników mineralnych. Dodatkowo stwierdzono niższe spożycie niezbędnych 
nienasyconych kwasów tłuszczowych oraz skrobi i błonnika pokarmowego u pacjentów z celiakią względem CD i WZJG. Najmniej różnic istotnie statystycznych występowało między chorymi na CD i WZJG. Spożycie wapnia we wszystkich badanych grupach było niewystarczające, aby pokryć dzienne zapotrzebowanie. Analiza statystyczna wyników morfologii krwi wykazała istotną różnicę w ilości monocytów u pacjentów z chorobą Crohna i wrzodziejącym zapaleniem jelita grubego. Pomiędzy chorymi na CD i celiakię różnica istotnie statystyczna dotyczyła RDW-CV, natomiast pomiędzy pacjentami z WZJG a celiakią różnica dotyczyła wartości erytrocytów, hematokrytu i MCV. Wnioski: Na podstawie oceny sposobu żywienia i morfologii należy stwierdzić, że wszystkie badane grupy narażone są na niedożywienie. Kaloryczność diety chorych na celiakię można zwiększyć przez dodanie skrobi ze źródeł bezglutenowych. We wszystkich grupach należy włączyć suplementację wapniem i witaminą $\mathrm{D}$ na takim samym poziomie. Dodatkowo ze względu na brak pełnego pokrycia zapotrzebowania wraz z dietą należy rozważyć suplementację potasu, magnezu i folianów szczególnie w grupie celiakii i CD. W celiakii suplementacja powinna dotyczyć także witaminy E, cynku, żelaza oraz jodu. Podaż błonnika w celiakii może być niewystarczająca. Obniżenie ilości erytrocytów i hematokrytu może sugerować występowanie WZJG. Niższe wartości płytek krwi, a w szczególności RDW-CV (\%), może zwiększać prawdopodobieństwo występowania celiakii, natomiast wzrost monocytów może być charakterystyczny dla CD.

Słowa kluczowe: wrzodziejące zapalenie jelita grubego; choroba Leśniowskiego-Crohna; celiakia; stan odżywienia; sposób żywienia; młodzież.

\section{WSTEP}

Pacjenci z przewlekłymi chorobami jelit często cierpią na niedobory składników pokarmowych wynikające zarówno z nieodpowiedniej diety, jak i gorszego wchłaniania składników odżywczych oraz pokarmowych. Ponadto grupa nastolatków z uwagi na intensywny wzrost i rozwój jest szczególnie narażona na wystąpienie konsekwencji zdrowotnych niedoborów.

Celem pracy było wykazanie różnic w sposobie żywienia nastolatków w trzech chorobach zapalnych jelit: chorobie Lesniowskiego-Crohna (CD), celiakii i wrzodziejącym zapaleniu jelita grubego (WZJG) oraz wskazanie, która grupa jest najbardziej narażona na niedobory pokarmowe. Dodatkowo w badaniach porównano stan odżywienia metodami antropometrycznymi z wyliczeniem wskaźnika masy ciała (body mass index - BMI) i obserwacją zmian parametrów morfologii pacjentów.

Wrzodziejące zapalenie jelita grubego i CD określane są jako nieswoiste zapalenia jelit (IBD) [1]. Chociaż choroba najczęściej występuje obecnie w Kanadzie i Europie, zachorowalność rośnie na całym świecie, a to oznacza, że IBD szybko staje się choroba globalną [2]. W ostatnich latach w województwie zachodniopomorskim zaobserwowano znaczny wzrost zachorowania na IBD [3]. Przyczyny oraz mechanizm powstawania są wciąż nie do końca poznane. Pomimo wielu badań nie udało się wyjaśnić dokładnej etiologii i patogenezy tych chorób, chociaż wiadomo, że biorą w nich udział czynniki środowiskowe, genetyczne i immunologiczne [4].

Dominującym czynnikiem jest środowisko, czyli styl życia, na który wpływa sposób żywienia, spożycie substancji chemicznych zawartych w żywności oraz umiejętność radzenia sobie ze stresem [5, 6]. Liczne substancje będące dodatkami do żywności powodują zmiany we florze jelitowej oraz zmieniają przepuszczalność błony jelit $[1,4]$. Wykazano, że spektrum mikrobiota u osób chorujących na nieswoiste zapalenia jelit różni się znacząco zarówno pod względem ilościowym, jak i jakościowym. Dodatkowo bierna ekspozycja na dym papierosowy zwiększa ryzyko zachorowania na CD [1]. Kolejnym przykładem środowiskowych czynników ryzyka są składniki chemiczne, czyli dodatki do żywności wykorzystywane w przemyśle spożywczym. Dzięki nim można przedłużyć trwałość żywności, ochronić przed skażeniem mikrobiologicznym, a co najważniejsze poprawić smak i teksturę produktów. Jednak dodatki takie w większej mierze wpływają negatywnie na organizm człowieka, a zwłaszcza na organizm dzieci z IBD. Działania niepożądane dotyczyć mogą nie tylko układu oddechowego, skóry czy zmiany zachowania, lecz także przewodu pokarmowego, powodując bóle brzucha, biegunki, nudności i wymioty [7]. Chassaing i wsp. udowodnili wpływ emulgatorów na zmiany mikroflory jelitowej [8]. Również inni autorzy przyczynę zwiększonej zachorowalności na IBD upatrują w dodatkach do żywności i współczesnej diecie [9].

Czynnik genetyczny predysponujący do wystąpienia choroby WZJG dotyczy genu umiejscowionego na 12 chromosomie IBD2, a w CD na 16 chromosomie - NOR/CARD15 [1]. W badaniach genetycznych udowodniono, że domena oligomeryzacji wiążącej nukleotydy 15/NAD2/CARD15 może zwiększać ryzyko wystąpienia CD. Badania genetyczne są szczególnie pomocne w diagnozowaniu dzieci, ponieważ warianty genów odpowiedzialnych za chorobę mówią o umiejscowieniu zapalenia w przewodzie pokarmowym [10].

W organizmie osób chorych dochodzi do patologicznych procesów dotyczących apoptozy komórek T znajdujących się w blaszkach błony śluzowej. W związku z tym organizm traci kontrolę nad reakcjami uwalniania mediatorów zapalnych i cytokin, podtrzymując stan zapalny w zajętym jelicie $[1,11]$. Ten przewlekły stan prowadzi do nasilonego stresu oksydacyjnego, przez który wytwarzane są wolne rodniki. Te zaś działają szkodliwie na błony komórek. W związku z tym należy pamiętać o diecie bogatej w przeciwutleniacze, które opóźniają utlenianie rodników [12].

Wrzodziejące zapalenie jelita może dotyczyć błony śluzowej jelita grubego, okrężnicy lub nawet odbytnicy, w konsekwencji powodując owrzodzenia i proces zapalny wyżej wymienionych miejsc. Wyróżnić można stan zaostrzenia, w którym dochodzi najczęściej do biegunek i krwawych stolców, oraz stan remisji, który może zostać zaburzony przez m.in. stres, antybiotykoterapię, zmianę nawyków żywieniowych oraz zakażenia i infekcje. Pomimo że choroba dotyka głównie ludzi w wieku 20-40 lat, u obu płci jednakowo, to dzieci są szczególnie narażone. 
Początki choroby najczęściej są skryte, a jedyne objawy to spadek masy ciała spowodowany brakiem łaknienia i nudnościami, a w konsekwencji wymiotami oraz znacznym zahamowaniem wzrostu. Leczenie w tej jednostce chorobowej skupia się na odpowiedniej diecie oraz lekach przeciwzapalnych [1].

Choroba Leśniowskiego-Crohna może dotyczyć każdego odcinka przewodu pokarmowego od jamy ustnej do odbytu. Finalnie w ścianie jelita cienkiego u większości pacjentów widoczne są skupiska nieserowaciejących, epitelioidalnych makrofagów, przez co dochodzi do zapalenia ziarniniakowego, charakterystycznego w CD [13]. Choroba Crohna występuje częściej u kobiet i młodych dziewcząt. Najczęściej dotkniętym odcinkiem jest jelito kręte, a dokładniej jego koniec. Cechą charakterystyczną choroby są odcinkowe zapalenia błony śluzowej przeplatane zdrowymi fragmentami jelita. Podobnie jak w WZJG początek choroby nie jest nagły. Głównym objawem oprócz bólu brzucha i biegunki tłuszczowej, która występuje po zajęciu większego odcinka przewodu pokarmowego, jest niedokrwistość [1], najczęściej spowodowana utratą żelaza we krwi z kałem oraz zaburzonym wchłanianiem składników odżywczych, w tym żelaza. Innym efektem występowania anemii w chorobach przewlekłych jest niekorzystny wpływ aktywacji szeregu reakcji immunologicznych oraz namnażania i różnicowania erytrocytów [14].

Kolejnymi objawami IBD są stany podgorączkowe, podwyższone CRP, hipoproteinemia, leukocy toza i trombocytoza [15]. Może się zdarzyć, co jest częste u osób chorych na CD, występowanie przetok, zarówno wewnętrznych, jak i zewnętrznych, a także pojedynczych lub mnogich [1]. Leczenie jest zazwyczaj kompleksowe, ponieważ dopiero wtedy widoczna jest jakakolwiek poprawa stanu zdrowia pacjenta. W skład takiego leczenia wchodzi odpowiednia dieta, uzupełnienie powstałych niedoborów, wprowadzenie leków hamujących procesy zapalne oraz leków o działaniu immunosupresyjnym [1].

Nieswoiste zapalenia jelit należą do chorób przewlekłych, które mogą w konsekwencji doprowadzić do wielu powikłań. Do powikłań WZJG należą: polipowatość zapalna, ostre rozdęcie okrężnicy (mega colon toxicum) i jelita. W przebiegu CD może dojść do powstania ropni między pętlami jelita i zwężenia jego światła. Może również wystąpić ostra niedrożność jelit, krwotok, a nawet perforacja jelit.

Powikłania pozajelitowe wrzodziejącego zapalenia jelita grubego dotyczy innych narządów, zaliczane są tutaj choroby wątroby (stłuszczenie wątroby, rak dróg żółciowych). Powikłania WZJG mogą również dotyczyć układu kostnego (osteoporoza, osteopenia), układu stawowego (zapalenie dużych stawów), skóry (rumień guzowaty) oraz oczu (zapalenie spojówek, zapalenie tęczówki) [1]. Stan zapalny toczący się w jelicie przyczynia się również do zmniejszonego wchłaniania składników pokarmowych takich jak elektrolity. Dodatkowo liczne biegunki mogą powodować zwiększoną utratę tych składników i w konsekwencji doprowadzić do zaburzeń gospodarki wodno-elektrolitowej.

Powikłania pozajelitowe CD, podobnie jak w przypadku WZJG, mogą dotyczyć układu kostnego (osteoporoza, osteopenia) czy układu moczowego (kamica żółciowa, kamica moczanowa) [11]. Dodatkowo w wyniku upośledzonego wchłaniania składników pokarmowych w jelicie oraz utraty ze stolcem żelaza, kwasu foliowego i kobalaminy, może dojść do rozwoju niedokrwistości. Obserwuję się również niedobór pierwiastków śladowych, np. cynku, na skutek upośledzonego wchłaniana oraz utraty podczas biegunek. Pierwiastek ten odgrywa pozytywną rolę w ograniczeniu stanu zapalnego toczącego się w organizmie oraz wpływa pozytywnie na odpowiedź immunologiczną. Niedobór cynku może pogorszyć proces regeneracji błony śluzowej i gojenia ran w całym organizmie [12].

Celiakia (choroba trzewna) jest przewlekłym zaburzeniem autoimmunologicznym, powodowanym przez stałą nietolerancję białek glutenu u osób, które są podatne genetycznie (haplotypy HLA-DQ2 i DQ8). Gluten natomiast jest mieszaniną białek magazynujących, tj. proliny (pszenica), hordeiny (jęczmień) i sekaliny (żyto). Wymienione białka mogą toksycznie działać na błonę śluzową jelit u osób uwarunkowanych genetycznie powodując szereg reakcji immunologicznych pośrednio odpowiedzialnych za zanik kosmków jelitowych [16]. Celiakia klasyfikowana jest jako jedna z najczęściej występujących chorób uwarunkowanych genetycznie, a w ostatnich latach zauważyć można wzrost zapadalności [17]. Z danych epidemiologicznych wynika, że na celiakię choruje ok. 1\% populacji całego świata [18].

W diagnostyce kluczowe jest zapalenie autoimmunologiczne błony śluzowej w jelicie cienkim, które cofa się po zastosowaniu diety bezglutenowej [19]. Wyróżniamy cztery kliniczne postacie celiakii:

- jawną, tj. klasyczną,

- niemą,

- utajoną,

- potencjalną.

Głównymi objawami klinicznymi są niskorosłość, anemia oraz deficyt masy ciała. Z danych wynika, iż częściej pojawiają się zaparcia niż biegunki. Czasem są to objawy dominujące i zarazem jedyne, jakie występują [19]. Jednak choroba trzewna może obejmować wiele narządów, stąd objawy mogą dotyczyć zaburzeń pracy serca, układu nerwowego, kostnego, funkcji wątroby i skóry [18]. Często dolegliwości w początkach choroby mogą być niespecyficzne, tzn. mogą mieć postać jedynie pozajelitową [17]. Jako że objawy choroby są wielopostaciowe, należy diagnozować dzieci oraz młodzież z niespecyficznymi dolegliwościami, takimi jak np. niedokrwistość z niedoboru żelaza, osteoporoza, zahamowanie rozwoju, oraz dzieci bez objawów, u których jednak istnieje ryzyko wystąpienia choroby, np. dzieci z chorobami autoimmunologicznymi i/lub wątroby [20].

Diagnostyka celiakii opiera się na oznaczeniu specyficznych przeciwciał w surowicy przeciwko transglutaminazie tkankowej 2, przeciwciała przeciwendomyzjalne oraz deamidowym peptydom gliadyny. Choroba rozpoznana może być również na podstawie obecności haplotytów HLA DQ2/HL DQ8 lub biopsji jelita cienkiego [13, 20]. Leczenie celiakii opiera się głównie na bezwzględnym przestrzeganiu diety bezglutenowej [19]. Stosowanymi zamiennikami są: ziemniaki, kukurydza, ryż, gryka, proso, soja, soczewica, fasola i ich przetwory a także produkty mniej popularne w Polsce: tapioka, maniok, sago, sorgo, amarant. 
Do odległych powikłań celiakii należą nowotwory jelit, przykładowo chłoniak jelita z komórek T występuje 40-100-krotnie częściej niż w populacji ogólnej. Dodatkowo może rozwinąć się rak gruczołowy jelita cienkiego, rak jamy ustnej, przełyku, dwunastnicy oraz jelita grubego. Jednak najczęstszym powikłaniem choroby trzewnej jest zaburzenie wchłaniania składników pokarmowych. Dzieje się tak za sprawą uszkodzonej śluzówki jelita cienkiego, co prowadzi do zmniejszonego wydzielania sekretyny oraz cholecystokininy, a to do obniżenia produkcji i wydzielania enzymów trzustkowych. W konsekwencji dochodzi do zaburzonego trawienia i wchłaniania białek, tłuszczów oraz witamin rozpuszczalnych w tłuszczach - A, D, E, K [21].

Ważnym aspektem w żywieniu osób z nieswoistymi zapaleniami jelit jest suplementacja probiotykami. Wpływają one korzystnie na organizm, lecząc stany zapalne toczące się w jelicie nawet u noworodków [22]. W badaniach naukowych udowodniono, że do zaczynu fermentacyjnego wykorzystywanego do produkcji chleba użyto pałeczek z rodzaju Lactobacillus i innych. Dzięki temu zmniejszyło się zanieczyszczenie glutenem produktów spożywczych [23]. Zatem stosowanie pieczywa wyrabianego na zakwasie, a nie na drożdżach ma również uzasadnienie $\mathrm{w}$ żywieniu pacjentów z nieswoistym zapaleniem jelit. Jest wiele badań z zastosowaniem colostrum, którego głównym składnikiem jest laktoferyna, świadczących o poprawie stanu zdrowia pacjentów. Laktoferyna bowiem skutecznie hamuje odpowiedź prozapalną makrofagów [24]. Działa ochronnie na komórki nabłonka jelita, promuje wzrost tkanki kostnej i przyspiesza odnowę funkcji systemu immunologicznego. Opisano kilka mechanizmów działania laktoferyny [25]. Jeden z nich polega na redukcji poziomu cytokin prozapalnych (TNF $\alpha$ i IL-1) oraz stymulacji wytwarzania cytokin przeciwzapalnych (IL-4 i IL-10) w tkankach jelita [26].

\section{MATERIAtY I METODY}

Grupę badaną stanowiło 26 pacjentów Poradni Gastroenterologicznej Samodzielnego Publicznego Szpitala Klinicznego $\mathrm{nr} 1 \mathrm{im}$. prof. Tadeusza Sokołowskiego w Szczecinie, u których choroba zapalna jelit była w remisji. W grupie WZJG było 8 osób, z CD - 8, z celiakią - 10. Były to grupy o równym udziale obu płci, odpowiednio w wieku 15,75 $\pm 1,75,14,8 \pm 1,99$ i 15,57 $\pm 2,50$ (tab. 1). W ocenie stanu odżywienia wykorzystano dane medyczne pacjentów dobrowolnie biorących udział w projekcie.

W grupie CD najczęściej zgłaszanymi dolegliwościami były: ból brzucha, biegunka, krew w stolcu, niski poziom żelaza. W grupie WZJG były to: krew w stolcu, ból brzucha, biegunki, wzdęcia, a w celiakii: ból brzucha, ból głowy, biegunki, mdłości, zmiany skórne, niskorosłość.

Sposób żywienia oceniono na podstawie wywiadu o spożyciu z ostatnich 24 godz. zebranego od pacjentów. Wielkość spożywanych porcji była określana za pomocą „Albumu fotografii produktów i potraw" [27]. Jadłospisy zostały wprowadzone do programu dietetycznego Dieta 5 d rekomendowanego przez Instytut Żywności i Żywienia (IŻŻ). W ocenie różnic stanu odżywienia wykorzystano pomiary antropometryczne - pomiar masy ciała $( \pm 0,1 \mathrm{~kg})$ i wzrostu $( \pm 0,5 \mathrm{~cm})$, wyliczając BMI oraz odnosząc go do odpowiednich siatek centylowych dla dziewcząt (ryc. 1) i chłopców (ryc. 2). Do porównania stanu odżywienia pomiędzy analizowanymi grupami pacjentów wykorzystano również morfologię krwi. Dane poddano analizie statystycznej przy użyciu programu Statistica 12 (Statsoft, Tulsa, Oklahoma, USA), wykorzystując test t dla prób niezależnych względem grup.

Uzyskane wyniki spożycia porównano z obowiązującymi normami żywienia dla populacji polskiej [28]. Pamiętając jednocześnie, że normy odnoszą się do osób zdrowych, a w stanach chorobowych mogą być niewystarczające do określenia spożycia białka, zastosowano zalecenia European Society for Clinical Nutrition and Metabolism (ESPEN) [29].

\section{WYNIKI}

Spożycie energii we wszystkich trzech grupach chorych nastolatków było niewystarczające (tab. 1), przy czym najbardziej narażeni na niedożywienie byli chorzy na celiakię (tab. 2). Odsetek energii z białka, tłuszczu i węglowodanów nie różnił się istotnie pomiędzy grupami, jednak zauważalne są różnice w zwiększeniu odsetka z tłuszczu w grupie z celiakią oraz odsetka białka w grupie z WZJG (tab. 3). Porównując spożycie białka ogółem oraz poszczególnych aminokwasów, stwierdzono istotnie niższe spożycie białka ogółem w grupie z celiakią i WZJG oraz białka roślinnego w grupie z celiakią i CD (tab. 4). Ponadto spożycie wszystkich aminokwasów oprócz lizyny było istotnie niższe $\mathrm{w}$ grupie $\mathrm{z}$ celiakią $\mathrm{w}$ porównaniu $\mathrm{z}$ grupą z WZJG, a dodatkowo cystyny nawet w porównaniu z grupą z CD (tab. 4). Stwierdzono również niższe spożycie niezbędnych nienasyconych kwasów tłuszczowych w grupie z celiakią względem grupy z WZJG oraz skrobi i błonnika pokarmowego w grupie z celiakią względem grup z WZJG i CD (tab. 2).

Prawie wszystkie składniki mineralne były spożywane na niższym poziomie w grupie z celiakią względem grupy z WZJG (tab. 2). Wyjątek stanowił wapń, którego spożycie we wszystkich grupach było bardzo niskie i wynosiło poniżej 60\% dziennego zapotrzebowania.

Charakteryzując spożycie witamin, stwierdzono ich istotnie niższą i lość w dietach osób chorych na celiakię w porównaniu z grupą z WZJG w spożyciu witaminy E i C, tiaminy, pirydoksyny oraz kwasu foliowego (tab. 2).

Analizując morfologię krwi pomiędzy grupami, stwierdzono istotnie niższe parametry w ilości erytrocytów oraz hematokrytu \% i MCV w grupie z celiakią w porównaniu z grupą z WZJG (tab. 5). Odnotowano również statystycznie istotne

TABELA 1. Charakterystyka badanych grup

\begin{tabular}{lccc}
\multicolumn{1}{c}{ Parametry } & CD* & Celiakia* & WZJG* \\
\hline Wiek & $15,750 \pm 1,753$ & $14,8 \pm 1,944$ & $15,571 \pm 2,507$ \\
\hline Masa ciała & $50,063 \pm 10,530$ & $52 \pm 19,875$ & $57,043 \pm 11,150$ \\
\hline Wzrost & $165,688 \pm 10,074$ & $159,100 \pm 15,487$ & $168,429 \pm 9,467$ \\
\hline
\end{tabular}

CD - choroba Leśniowskiego-Crohna; WZJG - wrzodziejące zapalenie jelita głównego; *brak istotnych różnic pomiędzy grupami 


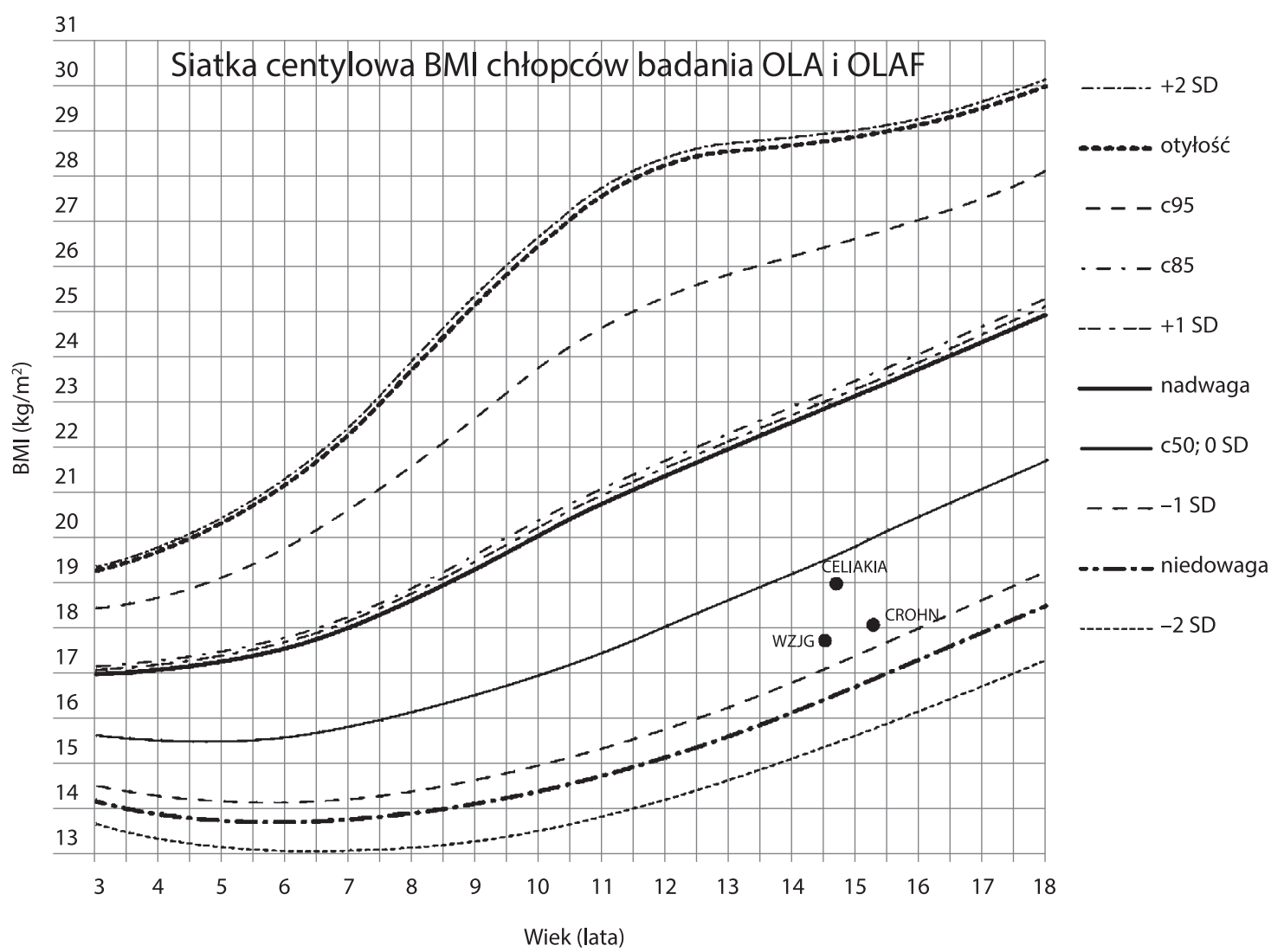

RYCINA 1. Średnia wartość wskaźnika masy ciała (BMI) u chłopców (średnia BMI w celiakii z pominięciem osoby otyłej leczonej sterydami na astmę)

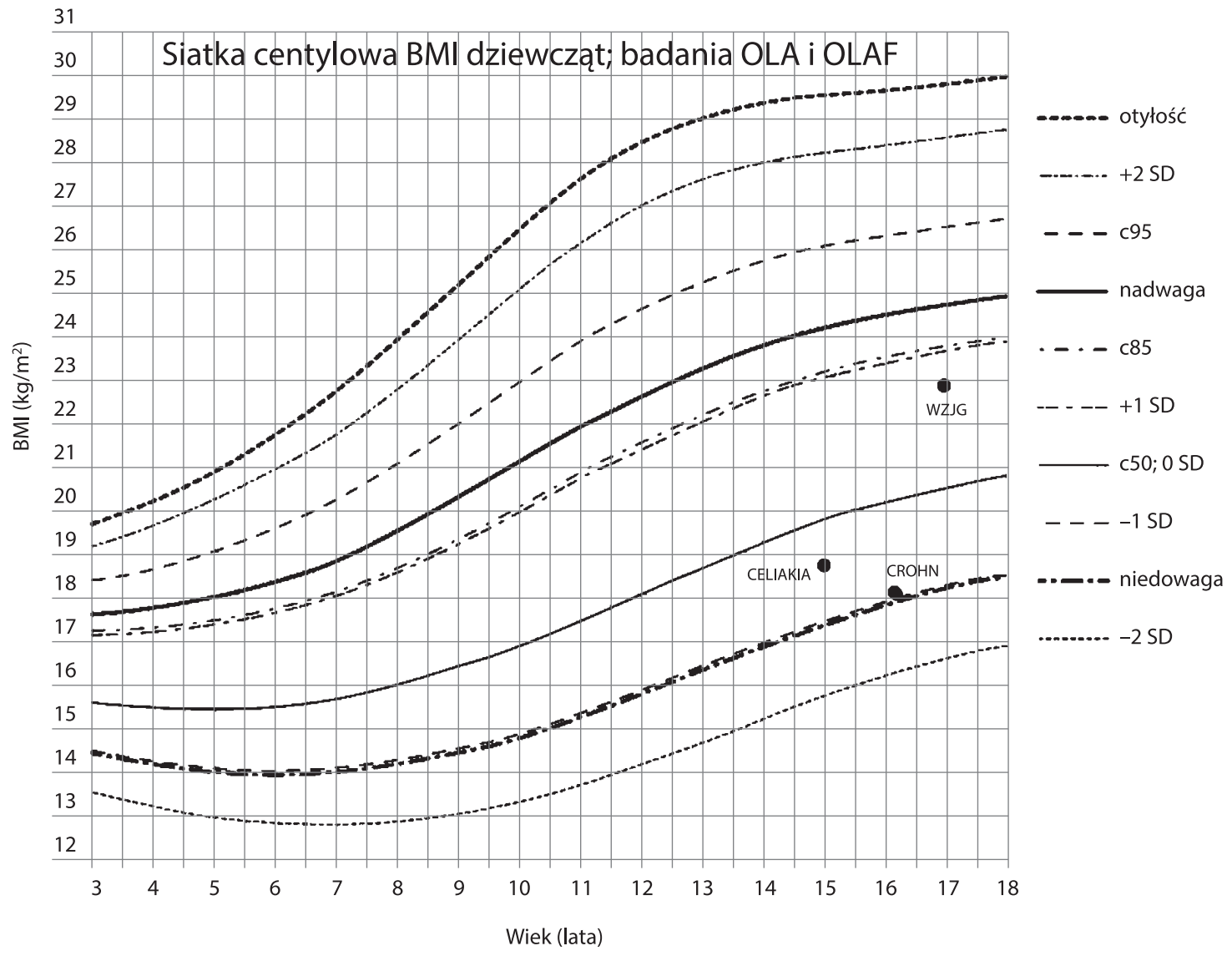

RYCINA 2. Średnia wartość wskaźnika masy ciała (BMI) u dziewcząt 
TABELA 2. Porównanie spożycia tłuszczu, węglowodanów, cholesterolu i składników pokarmowych pomiędzy grupami

\begin{tabular}{|c|c|c|c|c|c|c|c|}
\hline Nazwa składnika & Norma EAR & CD & Celiakia & WZJG & $\begin{array}{c}\text { CD } \\
\text { z celiakią }\end{array}$ & $\begin{array}{c}\text { CD } \\
\mathrm{z} \text { WZJG }\end{array}$ & $\begin{array}{l}\text { Celiakia } \\
\text { z WZJG }\end{array}$ \\
\hline Energia (kcal) & $2450 / 3000^{*}$ & 2147,9 & 1810,0 & 2296,7 & NS & NS & 0,016 \\
\hline Tłuszcz (g) & - & 78,397 & 69,674 & 74,792 & NS & NS & NS \\
\hline Kwasy tłuszczowe - ogółem nasycone (g) & - & 26,519 & 25,829 & 22,299 & NS & NS & NS \\
\hline Kwasy tłuszczowe - ogółem jednonienasycone (g) & - & 31,687 & 26,524 & 27,119 & NS & NS & NS \\
\hline Kwasy tłuszczowe - ogółem wielonienasycone (g) & - & 12,612 & 9,199 & 19,034 & NS & NS & 0,003 \\
\hline Długołańcuchowe wielonienasycone kwasy tłuszczowe (g) & - & 0,067 & 0,207 & 0,445 & NS & NS & NS \\
\hline Cholesterol (mg) & do 300 & 351,03 & 325,55 & 271,19 & NS & NS & NS \\
\hline Węglowodany ogółem (g) & - & 298,67 & 239,64 & 329,24 & NS & NS & 0,028 \\
\hline Węglowodany przyswajalne (g) & - & 277,83 & 226,09 & 305,02 & NS & NS & 0,042 \\
\hline Sacharoza (g) & 60 & 60,392 & 39,936 & 52,544 & NS & NS & NS \\
\hline Laktoza (g) & - & 5,454 & 5,274 & 5,968 & NS & NS & NS \\
\hline Skrobia (g) & - & 156,57 & 69,643 & 162,97 & 0,004 & NS & 0,002 \\
\hline Błonnik pokarmowy (g) & $19^{\#}$ & 20,845 & 13,545 & 24,267 & 0,008 & NS & 0,002 \\
\hline Popiół (g) & - & 15,274 & 12,855 & 17,401 & NS & NS & 0,035 \\
\hline Sód (mg) & $1500^{\#}$ & 3005,2 & 2480,0 & 2847,8 & NS & NS & NS \\
\hline Potas (mg) & 4700" & 3102,3 & 2394,9 & 3898,7 & NS & NS & 0,003 \\
\hline Wapń (mg) & 1100 & 550,42 & 588,08 & 571,56 & NS & NS & NS \\
\hline Fosfor (mg) & 1050 & 1254,4 & 1067,1 & 1653,6 & NS & NS & 0,005 \\
\hline Magnez (mg) & $300 / 340^{*}$ & 308,57 & 202,48 & 424,76 & NS & NS & 0,001 \\
\hline Żelazo (mg) & $8^{\#}$ & 10,376 & 7,807 & 12,671 & NS & NS & 0,001 \\
\hline Cynk (mg) & $7,3 / 8,5^{*}$ & 9,790 & 7,194 & 11,799 & NS & NS & 0,010 \\
\hline Miedź (mg) & 0,7 & 1,136 & 0,708 & 1,525 & 0,007 & NS & 0,000 \\
\hline Mangan (mg) & - & 4,316 & 2,114 & 5,864 & 0,004 & NS & 0,002 \\
\hline $\operatorname{Jod}(\mu \mathrm{g})$ & 95 & 127,21 & 82,054 & 105,07 & NS & NS & NS \\
\hline Witamina A - ekwiwalent retinolu $(\mu \mathrm{g})$ & $490 / 630^{*}$ & 1964,2 & 873,98 & 1109,7 & 0,049 & NS & NS \\
\hline Retinol $(\mu \mathrm{g})$ & - & 360,18 & 322,03 & 288,59 & NS & NS & NS \\
\hline Beta-karoten $(\mu \mathrm{g})$ & - & 9416,4 & 3153,1 & 4873,0 & NS & NS & NS \\
\hline Witamina E - ekwiwalent alfa-tokoferolu (mg) & $8 / 10^{* ; \#}$ & 10,119 & 7,049 & 14,206 & 0,037 & 0,02 & 0,000 \\
\hline Tiamina (mg) & $0,9 / 1,0^{*}$ & 1,329 & 0,806 & 1,680 & NS & NS & 0,002 \\
\hline Ryboflawina (mg) & $0,9 / 1,1^{*}$ & 1,485 & 1,227 & 1,556 & NS & NS & NS \\
\hline Niacyna $(\mathrm{mg})$ & $11 / 12^{*}$ & 20,466 & 18,522 & 29,471 & NS & NS & 0,049 \\
\hline Witamina $B_{6}(\mathrm{mg})$ & $1 / 1,1^{*}$ & 2,255 & 1,661 & 2,853 & NS & NS & 0,002 \\
\hline Witamina C (mg) & $55 / 65^{*}$ & 90,680 & 63,611 & 159,96 & NS & NS & 0,014 \\
\hline Foliany/kwas foliowy $(\mu \mathrm{g})$ & 330 & 257,32 & 191,22 & 312,55 & 0,032 & NS & 0,001 \\
\hline Witamina $B_{12}(\mu \mathrm{g})$ & 2 & 2,487 & 3,069 & 2,866 & NS & NS & NS \\
\hline Witamina $\mathrm{D}(\mu \mathrm{g})$ & 10 & 2,021 & 1,771 & 2,865 & NS & NS & NS \\
\hline
\end{tabular}

EAR - średnie zapotrzebowanie grupy; CD - choroba Leśniowskiego-Crohna; WZJG - wrzodziejące zapalenie jelita głównego; * dziewczęta/chłopcy; \# poziom Al (wystarczającego spożycia - poziom spożycia, przy którym u części osób mogą wystąpić objawy niedoborów)

TABELA 3. Porównanie odsetka energii ze składników odżywczych pomiędzy grupami

\begin{tabular}{|c|c|c|c|c|c|c|}
\hline Nazwa składnika & CD & Celiakia & WZJG & CD z celiakią & CD z WZJG & Celiakia z WZJG \\
\hline Odsetek energii z białka & 14,943 & 14,949 & 17,457 & NS & NS & NS \\
\hline Odsetek energii z tłuszczu & 31,988 & 34,021 & 29,146 & NS & NS & NS \\
\hline Odsetek energii z węglowodanów & 53,070 & 51,030 & 53,397 & NS & NS & NS \\
\hline
\end{tabular}

CD - choroba Leśniowskiego-Crohna; WZJG - wrzodziejące zapalenie jelita głównego

obniżenie poziomu RDW-CV (\%) w celiakii względem CD oraz monocytów (\%) w chorobie WZJG. Na uwagę zasługuje również obserwacja tendencji obniżonego P-LCR (\%) w CD względem WZJG. Pełnej morfologii w celiakii nie przeprowadzono (tab. 5).

\section{DYSKUSJA}

Pacjenci chorujący na IBD często skarżą się na objawy takie jak biegunki, wymioty, bóle brzucha, gorączka czy utrata łaknienia. 
TABELA 4. Porównanie spożycia białka i aminokwasów pomiędzy grupami

\begin{tabular}{|c|c|c|c|c|c|c|}
\hline Nazwa składnika & CD & Celiakia & WZJG & CD z celiakią & CD z WZJG & Celiakia z WZJG \\
\hline Białko ogółem (g)* & 80,590 & 67,989 & 97,781 & NS & NS & 0,005 \\
\hline Białko zwierzęce (g) & 50,954 & 52,026 & 62,224 & NS & NS & NS \\
\hline Białko roślinne (g) & 27,603 & 13,932 & 33,659 & 0,001 & NS & 0,000 \\
\hline Izoleucyna (mg) & 3830,647 & 3307,563 & 4801,507 & NS & NS & 0,006 \\
\hline Leucyna (mg) & 5920,484 & 5164,389 & 7270,661 & NS & NS & 0,007 \\
\hline Lizyna (mg) & 5259,458 & 4965,160 & 6679,397 & NS & NS & NS \\
\hline Metionina (mg) & 1913,505 & 1681,140 & 2375,017 & NS & NS & 0,009 \\
\hline Cystyna (mg) & 1246,401 & 810,488 & 1467,979 & 0,020 & NS & 0,000 \\
\hline Fenyloalanina (mg) & 3458,502 & 2870,319 & 4129,092 & NS & NS & 0,003 \\
\hline Tyrozyna (mg) & 2734,725 & 2505,814 & 3390,894 & NS & NS & 0,021 \\
\hline Treonina (mg) & 3149,614 & 2762,537 & 3879,961 & NS & NS & 0,013 \\
\hline Tryptofan (mg) & 1075,447 & 920,460 & 1291,918 & NS & NS & 0,017 \\
\hline Walina (mg) & 4468,997 & 3894,652 & 5593,328 & NS & NS & 0,007 \\
\hline Arginina (mg) & 3802,448 & 2937,004 & 4421,343 & NS & NS & 0,037 \\
\hline Histydyna (mg) & 2423,813 & 2026,646 & 2909,302 & NS & NS & 0,021 \\
\hline Alanina (mg) & 4015,938 & 3385,309 & 4935,863 & NS & NS & 0,010 \\
\hline Kwas asparaginowy (mg) & 7119,852 & 6374,948 & 8846,942 & NS & NS & 0,025 \\
\hline Kwas glutaminowy (mg) & 15384,449 & 11974,426 & 18379,795 & NS & NS & 0,001 \\
\hline Glicyna (mg) & 3607,406 & 2915,498 & 4461,259 & NS & NS & 0,014 \\
\hline Prolina (mg) & 5295,651 & 4139,741 & 6093,108 & NS & NS & 0,007 \\
\hline Seryna (mg) & 3730,566 & 3214,790 & 4433,345 & NS & NS & 0,013 \\
\hline
\end{tabular}

CD - choroba Leśniowskiego-Crohna; WZJG - wrzodziejące zapalenie jelita głównego; * zgodnie z zaleceniami ESPEN dzienne spożycie białka powinno wynosić 80-120 g

TABELA 5. Porównanie morfologii pomiędzy grupami

\begin{tabular}{|c|c|c|c|c|c|c|c|}
\hline Parametr & $\begin{array}{l}\text { Wartości } \\
\text { referencyjne }\end{array}$ & CD & Celiakia & WZJG & $\begin{array}{c}\text { CD } \\
\text { z celiakią }\end{array}$ & $\begin{array}{c}\text { CD } \\
\text { z WZJG }\end{array}$ & $\begin{array}{c}\text { Celiakia } \\
\text { z WZJG }\end{array}$ \\
\hline Leukocyty (tys/ $\mu \mathrm{L})$ & $3,8-10$ & $7,373 \pm 3,91$ & $6,444 \pm 0,98$ & $7,885 \pm 3,3$ & NS & NS & NS \\
\hline Erytrocyty $(\mathrm{mln} / \mu \mathrm{L})$ & $4,2-5,6$ & $4,849 \pm 0,48$ & $4,961 \pm 0,16$ & $4,441 \pm 0,31$ & NS & NS & 0,002 \\
\hline Hemoglobina ( $\mathrm{g} / \mathrm{dL}$ ) & $12-15,5$ & $12,971 \pm 1,16$ & $13,743 \pm 0,76$ & $12,95 \pm 0,55$ & NS & NS & NS \\
\hline Hematokryt (\%) & $35-49$ & $38 \pm 2,44$ & $39,343 \pm 2,31$ & $37,063 \pm 1,15$ & NS & NS & 0,042 \\
\hline MCV (fl) & $77-92$ & $79,029 \pm 8,98$ & $79,257 \pm 2,90$ & $83,7 \pm 4,247$ & NS & NS & 0,030 \\
\hline $\mathrm{MCH}(\mathrm{pg})$ & $26,5-32,5$ & $26,986 \pm 3,74$ & $27,686 \pm 0,92$ & $29,263 \pm 1,93$ & NS & NS & NS \\
\hline $\mathrm{MCHC}(\mathrm{g} / \mathrm{dL})$ & $32,4-36,8$ & $34,1 \pm 1,086$ & $34,929 \pm 0,7$ & $35 \pm 0,904$ & NS & NS & NS \\
\hline Płytki krwi (tys/ $\mu \mathrm{L})$ & $180-430$ & $337,86 \pm 122,2$ & $264,14 \pm 46,54$ & $280 \pm 83,95$ & NS & NS & NS \\
\hline RDW-CV (\%) & $11,4-14,8$ & $14,057 \pm 1,26$ & $12,900 \pm 0,40$ & $13,614 \pm 1,06$ & NS & 0,039 & NS \\
\hline MPV (fl) & $9-13$ & $9,757 \pm 0,67$ & $10,229 \pm 0,4$ & $10,357 \pm 0,57$ & NS & NS & NS \\
\hline P-LCR (\%) & $19,2-47$ & $22 \pm 5,79$ & $25,286 \pm 2,65$ & $27,171 \pm 4,70$ & $\mathrm{NS}^{*}$ & NS & NS \\
\hline РСТ (\%) & $0,17-0,35$ & $0,326 \pm 0,12$ & $0,264 \pm 0,04$ & $0,273 \pm 0,08$ & NS & NS & NS \\
\hline Neutrofile (\%) & $46-75$ & $57,467 \pm 11,26$ & - & $56,740 \pm 16,69$ & NS & - & - \\
\hline Limfocyty (\%) & $15-45$ & $26,567 \pm 11,69$ & - & $22,392 \pm 15,98$ & NS & - & - \\
\hline Monocyty (\%) & $2-10$ & $12,833 \pm 2,92$ & - & $7,352 \pm 4,0$ & 0,022 & - & - \\
\hline
\end{tabular}

CD - choroba Leśniowskiego-Crohna; WZJG - wrzodziejące zapalenie jelita głównego; *0,066304

Są to symptomy, które obok niedoborowej diety mogą dodatkowo przyczyniać się do rozwoju niedożywienia [30]. Niedobory żywieniowe w tej grupie pacjentów wynikają nie tylko z zaburzeń trawienia czy wchłaniania, lecz również ze zwiększonych potrzeb energetycznych i spożycia niektórych składników pokarmowych związanych z zapaleniem [31]. Niedożywienie może być spowodowane także utrudnionym wchłanianiem witaminy $\mathrm{B}_{9}$ oraz nasilonym katabolizmem wynikającym z przyjmowania leków sterydowych, które również ograniczają wchłanianie witaminy $\mathrm{B}_{6}$ [31]. Stwierdzono, że niedożywienie białkowo-kaloryczne częściej dotyka pacjentów z CD niż z WZJG [30]. Potwierdza się to w omawianym badaniu. Pacjenci z WZJG wykazywali zarówno lepsze pokrycie zapotrzebowania kalorycznego (2295,9 vs 2115,2 kcal/dzień; $p=0,016$ ) wraz $\mathrm{z}$ dietą, jak i białkowego w stosunku do chorujących na CD (97,7 vs 80,5 g/dzień; $\mathrm{p}=$ 0,04). Z kolei żywieniowe zalecenia dla nieswoistych chorób zapalnych jelit sformułowane przez ESPEN rekomendują dietę w CD z zawartością białka 
80-120 g/dzień [30], co oznacza, że wszyscy pacjenci w różnym stopniu są narażeni na niedożywienie białkowe. Aminokwasami ograniczającymi przyswajalność pozostałych są tryptofan, metionina, histydyna i arginina, które znajdują się w mięsie, rybach, nabiale i nasionach roślin strączkowych. W żywieniu takich pacjentów można również wspomóc się wysokobiałkowymi dietami przemysłowymi.

W grupie pacjentów z CD zaobserwowano tendencję do ograniczania spożycia węglowodanów [32]. W badaniach własnych wykazano istotnie statystycznie różnicę w spożyciu węglowodanów ogółem w grupie z celiakią względem WZJG, ale porównywalne względem CD. Ponadto w badaniu Amre i wsp. wykazano mniejsze spożycie błonnika pokarmowego w grupie pacjentów chorujących na CD w porównaniu z grupą kontrolną. W badaniach własnych stwierdzono niskie spożycie we wszystkich trzech grupach badanych, przy czym najniższe w celiakii, co będzie sprzyjało występowaniu zaparć [19].

Brasil Lopes i wsp. zwrócili uwagę na niedobory wapnia w diecie osób dorosłych z IBD [33]. Szczególnie ma to miejsce w zaostrzeniu CD i WZJG ze względu na eliminację z diety nabiału. Zawartość wapnia w diecie we wszystkich grupach nie zapewnia prawidłowej podaży tego makroskładnika; podobna sytuacja dotyczy witaminy D. Niedobory wapnia i witaminy D mogą przyczynić się do wystąpienia osteoporozy i osteopenii, ale u tak młodego organizmu będą przyczyną wad rozwojowych całego układu kostnego [12]. W przypadku mikroskładników jak cynk czy żelazo Amre i wsp. wykazali, że pacjenci z CD spożywają większą ilość tych pierwiastków, jednak pochodzą one z suplementów, a nie z diety. Wskazana jest suplementacja cynkiem pokrywająca zwiększone zapotrzebowanie z powodu gojenia ran śluzówki jelit oraz zwiększonej reaktywności układu immunologicznego. Pacjenci z WZJG spożywali istotnie statystycznie więcej żelaza niż pacjenci z celiakią, jednak z uwagi na możliwość występowania zaostrzenia stanu z towarzyszącą krwią w stolcu jego spożycie również wydaje się zbyt niskie we wszystkich grupach. Podaż witaminy $B_{12} \mathrm{~W}$ obu grupach znajdowała się na odpowiednim poziomie w stosunku do rekomendacji IŻŻ dla zdrowych dzieci na poziomie zalecanego dziennego spożycia. Jednakże u pacjentów chorujących na CD może występować niedobór tej witaminy w organizmie ze względu na niewystarczającą absorpcję z diety i suplementów [12].

Osoby cierpiące na celiakię nawet o tym nie wiedząc, nie dostarczają do organizmu wystarczających ilości składników odżywczych z diety. Młode osoby w okresie wzrostu i rozwoju powinny szczególnie zwracać uwagę na dobór spożywanych pokarmów, a pacjenci, którzy są dotknięci chorobą ze spektrum IBD, powinni być pod stałą opieką gastrologa i dietetyka. Spośród analizowanych chorób celiakia jest chorobą najbardziej narażającą na niedobory energii, witamin, makro- i mikroelementów. Jest to spowodowane koniecznością stosowania diety bezglutenowej, która ogranicza pacjenta w doborze produktów spożywczych. Sama dieta zawiera znacznie mniej wartości odżywczych i pokarmowych ze względu na przeprowadzenie odpowiedniego procesu technologicznego pozwalającego oczyścić produkt z białek, których nie toleruje dziecko. Takie produkty zawierają zazwyczaj mniejszą ilość witaminy D, witaminy $B_{1}$, magnezu, wapnia, żelaza, cynku czy błonnika pokarmowego, co zostało udowodnione w pracy. Innym problemem, z którym borykają się osoby chorujące, jest cena produktów bezglutenowych, zazwyczaj 2-krotnie wyższa niż tych samych produktów zawierających gluten. Specjalne produkty bezglutenowe zawierają często mnóstwo konserwantów i dodatków do żywności, które mogą wzmagać dolegliwości żołądkowo-jelitowe mimo wykluczenia glutenu. Dlatego rodzice kupując i komponując posiłki dla dzieci, sięgają częściej po produkty naturalne, które nie zawierają glutenu, jak kasze, nasiona roślin strączkowych, orzechy, nasiona słonecznika, sezamu i inne. Jednakże i te produkty nie są wystarczające do zaspokojenia potrzeb żywieniowych chorych [34]. Jednym ze sposobów zwiększenia kaloryczności diety może być również zwiększenie udziału skrobi ziemniaczanej, ponieważ skrobi w diecie szczególnie osób z celiakią było znacznie mniej z powodu wyeliminowania zbóż.

Inne badania wykazują, że dzieci chorujące na celiakię miały niedostateczne spożycie tłuszczu [35]. Badania własne nie potwierdzają niedostatecznego spożycia tłuszczu ogółem, ale obserwowane jest niskie spożycie niezbędnych nienasyconych kwasów tłuszczowych, w tym EPA i DHA, których ważnym zadaniem jest zmniejszanie procesu zapalnego [36]. Costea i wsp. wykazali podatność osób z niektórymi polimorfizmami genów $C_{4} P_{4} F_{3}$ oraz FADS2 na występowanie CD przy zwiększony spożyciu tłuszczy omega-6/omega-3 [37].

W badaniach Ohlund i wsp. jakość węglowodanów charakteryzowała się wysoką zawartością sacharozy, czego nie zaobserwowano w badaniach własnych, chociaż tendencja taka jest zauważalna, jeśli ma się na uwadze, że górna granica to $60 \mathrm{~g} /$ dzień [35].

Ponadto dzieci chorujące na celiakię powinny dokładnie czytać etykiety produktów spożywczych, ponieważ produkty potencjalnie wolne od glutenu często go posiadają [38]. Gluten dodawany jest do żywności w procesach technologicznych wyrobu większości wędlin, serów pleśniowych i napojów mlecznych. Chociaż nie jest uznany za dodatek do żywności, stosuje się go jako wypełniacz, zagęszczacz czy nośnik barwników. Nieumiejętne posługiwanie się etykietami oraz brak konsekwencji w stosowaniu diety może powodować szkody w organizmie dziecka, a tym samym uszkadzać kosmki jelitowe.

Badania morfologiczne krwi wykazały prawidłowe wyniki dla wszystkich parametrów poza monocytami u pacjentów z CD. Monocyty w tej grupie były podwyższone $(12,833 \pm 2,925)$. Monocy ty razem z aktywowanymi limfocytami są komórkami produkującymi $\mathrm{TNF} \alpha$, który jest cytokiną zapalną i przyczynia się do występowania zapalenia w układzie pokarmowym w obu omawianych chorobach [39]. Osoby chorujące na celiakię miały nieznacznie podwyższone monocyty, które świadczą o panującym w jelicie stanie zapalnym.

Innym parametrem morfologii jest obniżone RDW-CV, które może być przyczyną anemii.

W prezentowanych badaniach tylko jedno dziecko miało BMI powyżej normy; nie jest jasne, czy dieta bezglutenowa, na której było, jest odpowiedzialna bezpośrednio za wzrost 
masy ciała w stosunku do wzrostu. Prawdopodobnie nałożyło się na ten efekt wiele czynników, również astma leczona sterydami. Pamiętać należy, że nadzór dietetyków ma kluczowe znaczenie dla równowagi żywieniowej, jednak nie zawsze jest gwarantem prawidłowej diety [40].

\section{WNIOSKI}

Na podstawie oceny sposobu żywienia, pomiarów antropometrycznych i morfologii nastolatków należy stwierdzić, że wszystkie trzy grupy są narażone na niedożywienie. Najbardziej zagrożoną niedożywieniem białkowo-kalorycznym jest młodzież z celiakią, a najmniej z WZJG. Zarówno w celiakii, jak i CD należy uwzględnić uzupełnienie diety w pełnowartościowe białko. Kaloryczność diety chorych na celiakię można, a nawet należy zwiększyć przez dodanie skrobi ze źródeł bezglutenowych.

We wszystkich grupach należy włączyć suplementację wapniem i witaminą $D$ na takim samym poziomie. $Z$ uwagi na brak pokrycia pełnego zapotrzebowania na składniki pokarmowe należy uwzględnić suplementację potasu, magnezu i folianów, szczególnie w grupie z celiakią i CD. Grupa z celiakią powinna również być suplementowana tiaminą, witaminą E, cynkiem, żelazem i jodem. Z uwagi jednak na zwiększone zapotrzebowanie pacjentów wynikające z choroby jelit może być wskazana szersza suplementacja. Podaż błonnika w celiakii nie jest wystarczająca i może być głównym powodem trudności z wypróżnianiem. Obniżenie ilości erytrocytów i hematokrytu może sugerować WZJG. Niższe wartości płytek krwi, a w szczególności RDW-CV (\%), może zwiększać prawdopodobieństwo występowania celiakii. Z kolei wzrost monocytów może być charakterystyczny dla CD.

\section{PIŚMIENNICTWO}

1. Bartnik W. Wytyczne postępowania w nieswoistych chorobach zapalnych jelit. Prz Gastroenterol 2007;2(5):215-29.

2. Molodecky NA, Soon IS, Rabi DM, Ghali WA, Ferris M, Chernoff G, et al. Increasing incidence and prevalence of the inflammatory bowel diseases with time, based on systematic review. Gastroenterology 2012;142(1):4654. doi: 10.1053/j.gastro.2011.10.001.

3. Czaja-Bulsa G, Kurzawska-Piszczek A, Bulsa M. Nieswoiste zapalenia jelit u dzieci z regionu Pomorza Zachodniego. Fam Med Prim Care Rev 2006;8(3):578-81.

4. Kamińska B., Landowski P. Rola wybranych czynników środowiskowych w etiopatogenezie nieswoistych zapaleń jelit. Forum Med Rodz 2009;3(1):42-8.

5. Camara RJ, Ziegler R, Begre S, Schoepfer AM, von Kanel R. The role of psychological stress in inflammatory bowel disease: quality assessment of methods of 18 prospective studies and suggestion for future research. Digestion 2009;80(2):129-39. doi: 10.1159/000226087.

6. Maunder RG, Levenstein S. The role of stress in the development and clinical course of inflammatory bowel disease: epidemiological evidence. Curr Mol Med 2008;8(4):247-52.

7. Wójtowicz A. Dodatki żywieniowe - ich rola w chorobach alergicznych u dzieci. Pediatr Dypl 2011;15(4):71-4.

8. Chassaing B, Van de Wiele T, Gewirtz A. 0-013 dietary emulsifiers directly impact the human gut microbiota increasing its pro-inflammatory potential and ability to induce intestinal inflammation. Inflamm Bowel Dis 2017;23 Duppl 1:S5. doi: 10.1097/01.MIB.0000 512523.29952.6f.
9. Dixon LJ, Kabi A, Nickerson KP, McDonald C. Combinatorial effects of diet and genetics on inflammatory bowel disease pathogenesis. Inflamm Bowel Dis 2015;21(4):912-22. doi: 10.1097/MIB.0000000000000289.

10. Salkic NN, Adler G, Zawada I, Alibegovic E, Karakiewicz B, Kozłowska-Wiechowska A, et al. NOD2/CARD15 mutations in Polish and Bosnian populations with and without Crohn's disease: prevalence and genotype-phenotype analysis. Bosn J Basic Med Sci 2015;15(2):67-72. doi: 10.17305/bjbms.2015.348.

11. Kosińska B. Diagnostyka laboratoryjna nieswoistych zapaleń jelit. Now Lek 2006;75(4)382-8.

12. Baczewska-Mazurkiewicz D, Rydzewska G. Problemy żywieniowe pacjentów z nieswoistymi chorobami zapalnymi jelit. Prz Gastroenterol 2011;6:69-77.

13. Bąk E, Soszka A, Stelmaszuk T, Dyrla P, Gil J. The assessment the quality of life in patients with Crohn's disease. Nowa Med 2015;2:45-53. doi: 10.5604/17312485.1167004.

14. Radwan R, Radwan-Kwiatek K, Skrzydło-Radomańska B, Rydzewska G. Niedokrwistość w nieswoistych zapaleniach jelit - etiopatogeneza, rozpoznawanie i leczenie. Prz Gastroenterol 2010;5(6):315-20.

15. Wojtuń S, Gil J, Szwed $Ł$, Dyrla P. Podstawowe objawy i różnicowanie nieswoistych chorób zapalnych jelit. Pediatr Med Rodz 2014;10(1):61-6.

16. Penagini F, Dilillo D, Meneghin F, Mameli C, Fabiano V, Zuccotti GV. Gluten-free diet in children: an approach to a nutritionally adequate and balanced diet. Nutrients 2013;5(11):4553-65. doi: 10.3390/nu5114553.

17. Krawiec P, Pac-Kożuchowska E. Różny obraz celiakii wśród dzieci. Prz Med Uniw Rzesz Inst Leków 2012;2:193-9.

18. Boroń-Kaczmarska A. Celiakia a choroby wątroby. Med Sci Rev Hepatol 2009;9:102-5.

19. Radlović N, Mladenowić M, Leković Z, Zivanović D, Brdar R, Radlović V et al. Effect of gluten-free diet on the growth and nutritional status of children with coeliac disease. Srp Arh Celok Lek 2009;137(11-12):632-7.

20. Franciszek I, Franciszek B. Nowe wytyczne dotyczące diagnostyki i leczenia choroby trzewnej u dzieci i młodzieży. Prz Gastroenterol 2012;7(4):185-91.

21. Satora D, Bochen K, Prystupa A, Pietraszek-Mamcarz J, Mosiewicz J, Schabowski J. Celiakia - choroba nie tylko dziecięca. Fam Med Primary Care Rev 2011;13(1):90-4.

22. Jiang F, Meng D, Weng M, Zhu W, Wu W, Kasper D, et al. The symbiotic bacterial surface factor polysaccharide A on Bacteroides fragilis inhibits IL-1 $\beta$ induced inflammation in human fetal enterocytes via toll receptors 2 and 4. PLoS One 2017;12(3):e0172738. doi: 10.1371/journal.pone.0172738.

23. Kędzia A. Działanie probiotyków na organizm człowieka. Cz. II. Zastosowanie probiotyków w leczeniu i profilaktyce chorób. Post Fitoter 2009;1:50-7.

24. Majka G, Więcek G, Śróttek M, Śpiewak K, Brindell M, Koziel J, et al. The impact of lactoferrin with different levels of metal saturation on the intestinal epithelial barrier function and mucosal inflammation. Biometals 2016;29(6):1019-33. doi: 10.1007/s10534-016-9973-x.

25. Zimecki M, Artym J. Właściwości terapeutyczne białek i peptydów z siary i mleka. Postępy Hig Med Dośw 2005;59:309-23.

26. Togawa J, Nagase $H$, Tanaka K, Inamori M, Nakajima A, Ueno N, et al. Oral administration of lactoferrin reduces colitis in rats via modulation of the immune system and correction of cytokine imbalance. J Gastroenterol Hepatol 2002;17(12):1291-8.

27. Szponar L, Wolnicka K, Rychlik E. Album fotografii produktów i potraw. Warszawa: Instytut Żywności i Żywienia; 2000.

28. Jarosz M. Normy żywienia dla populacji polskiej - nowelizacja. Warszawa: Instytut Żywności i Żywienia; 2012.

29. Ciborowska H, Rudnicka A. Dietetyka. Żywienie zdrowego i chorego. Warszawa: PZWL; 2014.

30. Włochal M, Grzymisławski M. Nowe trendy leczenia żywieniowego w przypadku nieswoistych chorób zapalnych jelit. Piel Zdr Publ 2016;6(2):14958. doi: 10.17219/pzp/61571.

31. Pieczyńska J, Prescha A, Zabłocka-Słowińska K, Neubauer K, Smerka A, Januszewicz A, et al. Test minimalnej oceny stanu odżywienia jako uniwersalne narzędzie do oceny stanu odżywienia i psychologicznego chorych na nieswoiste choroby zapalne jelit - badania wstępne. Hygeia Public Health 2014;49(2):274-8.

32. Amre DK, D'Souza S, Morgan K, Seidman G, Lambrette P, Grimard G, et al. Imbalances in dietary consumption of fatty acids, vegetables, and fruits are associated with risk for Crohn's disease in children. Am J Gastroenterol 2007;102(9):2016-25. doi: 10.1111/j.1572-0241.2007.01411.x. 
33. Brasil Lopes M, Rocha R, Castro Lyra A, Rosa Oliveira V, Gomes Coqueiro F, Silveira Almeida N, et al. Restriction of dairy products; a reality in inflammatory bowel disease patients. Nutr Hosp 2014;29(3):575-81. doi: 10.3305/nh.2014.29.3.7124.

34. Myszkowska-Ryciak J, Harton A, Gajewska D. Analiza wartości odżywczej i kosztów diety bezglutenowej w porównaniu do standardowej racji pokarmowej. Med Ogólna Nauki Zdr 2015;21(3):312-6.

35. Ohlund K, Olsson C, Hernell O, Ohlund I. Dietary shortcomings in children on a gluten-free diet. J Hum Nutr Diet 2010;23(3):294-300. doi: 10.1111/j.1365-277X.2010.01060.x.

36. Bosviel R, Joumard-Cubizolles L, Chinetti-Gbaguidi G, Bayle D, Copin C, Hennuyer N, et al. DHA-derived oxylipins, neuroprostanes and protectins, differentially and dose-dependently modulate the inflammatory response in human macrophages: Putative mechanisms through PPAR activation. Free Radic Biol Med 2017;103:146-54. doi: 10.1016/j.freeradbiomed.2016.12.018.

37. Costea I, Mack DR, Lemaitre RN, Israel D, Marcil V, Ahmad A, et al. Interactions between the dietary polyunsaturated fatty acid ratio and genetic factors determine susceptibility to pediatric Crohn's disease. Gastroenterology 2014;146(4):929-31. doi: 10.1053/j.gastro.2013.12.034

38. Swora E, Stankowiak-Kulpa H, Mazur M. Dieta bezglutenowa w chorobie trzewnej. Now Lek 2009;78(5-6):324-9.

39. Wegner A, Dądalski M, Ryżko J, Kierkuś J. Terapia w chorobie Leśniowskiego-Crohna u dziecka. Opis przypadku. Post Nauk Med 2014;27(3):172-7.

40. Reilly NR, Aguilar K, Hassid BG, Cheng J, Defelice AR, Kazlow P, et al. Celiac disease in normal-weight and overweight children: clinical features and growth outcomes following a gluten-free diet. J Pediatr Gastroenterol Nutr 2011;53(5):528-31. doi: 10.1097/MPG.0b013e3182276d5e. 